\title{
Retardasi Mental
}

\author{
Titi Sunarwati Sularyo, Muzal Kadim
}

\begin{abstract}
Retardasi mental adalah penurunan fungsi intelektual yang menyeluruh secara bermakna dan secara langsung menyebabkan gangguan adaptasi sosial, dan bermanifestasi selama masa perkembangan. Klasifikasi retardasi mental adalah mild retardation, moderate retardation, severe retardation dan profound retardation.

Etiologi retardasi mental dapat terjadi mulai dari pranatal, perinatal dan postnatal. Beberapa penulis secara terpisah menyebutkan lebih dari 1000 macam penyebab terjadinya retardasi mental, dan banyak diantaranya yang dapat dicegah. Ditinjau dari penyebab secara langsung dapat digolongkan atas penyebab biologis dan psikososial.

Diagnosis retardasi mental tidak hanya didasarkan atas uji intelegensia saja, melainkan juga dari riwayat penyakit, laporan dari orangtua, laporan dari sekolah, pemeriksaan fisis, laboratorium, pemeriksaan penunjang.

Tata laksana retardasi mental mencakup tatalaksana medis, penempatan di panti khusus, psikoterapi, konseling, dan pendidikan khusus. Pencegahan retardasi mental dapat primer (mencegah timbulnya retardasi mental), atau sekunder (mengurangi manifestasi klinis retardasi mental).
\end{abstract}

Kata kunci: retardasi mental, Inteligence Quotient (IQ), adaptasi sosial, masa perkembangan

$\mathcal{R}$ etardasi mental merupakan suatu kelainan mental seumur hidup, diperkirakan lebih dari 120 juta orang di seluruh dunia menderita kelainan ini. ${ }^{1}$ Oleh karena itu retardasi mental merupakan masalah di bidang kesehatan masyarakat, kesejahteraan sosial dan pendidikan baik pada anak yang mengalami retardasi mental tersebut maupun keluarga dan masyarakat. Retardasi mental merupakan suatu keadaan penyimpangan tumbuh kembang seorang anak sedangkan peristiwa tumbuh kembang itu sendiri merupakan proses utama, hakiki, dan khas pada anak serta merupakan sesuatu yang terpenting

Kepala Subbagian Pediatri Sosial, Bagian Ilmu Kesehatan Anak FKUIRSCM (Dr. Titi Sunarwati Sularyo, Sp.A(K)), Program Pendidikan Dokter Spesialis (PPDS), Bagian Ilmu Kesehatan Anak FKUI-RSCM, Jakarta (Dr. Muzal Kadim).

Alamat korespondensi:

Dr. Titi Sunarwati Sularyo, Sp.A(K).

Subbagian Pediatri Sosial, Bagian Ilmu Kesehatan Anak FKUI-RSCM, Jl. Salemba 6, Jakarta 10430 .

Tel.: 021- 316 0622. Fax.: 3913982. pada anak tersebut. Terjadinya retardasi mental dapat disebabkan adanya gangguan pada fase pranatal, perinatal maupun postnatal. Mengingat beratnya beban keluarga maupun masyarakat yang harus ditanggung dalam penatalaksanaan retardasi mental, maka pencegahan yang efektif merupakan pilihan terbaik. ${ }^{2,3}$

Pada zaman dahulu orang tidak begitu membedakan antara deformitas fisik bawaan seperti kerdil dan lain-lain dengan retardasi mental. Penderita epilepsi, psikosis, tuna rungu-wicara sering dicampuradukkan dengan mereka yang terganggu intelektualnya. Pada kenyataannya memang keadaan-keadaan tersebut sering menyertai penderita retardasi mental, sehingga menyulitkan untuk membuat diagnosis klinis.

Pada masa kerajaan Yunani di bawah hukum Lycurgus anak dengan retardasi mental mengalami perlakuan yang sangat mengenaskan, yang dibolehkan untuk dimusnahkan, atau dibuang di sungai Eurotes. Di Romawi kuno ada hukum yang membenarkan pembunuhan pada anak-anak yang cacat atau yang 
lemah, walaupun kadang-kadang anak cacat tersebut masih dipertahankan hidup bila masih mampu menghibur para pembesar.

Prevalens retardasi mental pada anak-anak di bawah umur 18 tahun di negara maju diperkirakan mencapai $0,5-2,5 \%$, di negara berkembang berkisar $4,6 \%$. Insidens retardasi mental di negara maju berkisar 3-4 kasus baru per 1000 anak dalam 20 tahun terakhir. Angka kejadian anak retardasi mental berkisar 19 per 1000 kelahiran hidup. ${ }^{1}$ Banyak penelitian melaporkan angka kejadian retardasi mental lebih banyak pada anak laki-laki dibandingkan perempuan. ${ }^{1,4-6}$

Tujuan penulisan ini adalah untuk membahas retardasi mental secara umum, dan akan dibahas tentang definisi, klasifikasi, etiologi, diagnosis serta tatalaksana serta pencegahan retardasi mental.

\section{Definisi}

American Association on Mental Deficiency (AAMD) membuat definisi retardasi mental yang kemudian direvisi oleh Rick Heber (1961) sebagai suatu penurunan fungsi intelektual secara menyeluruh yang terjadi pada masa perkembangan dan dihubungkan dengan gangguan adaptasi sosial. Ada 3 hal penting yang merupakan kata kunci dalam definisi ini yaitu penurunan fungsi intelektual, adaptasi sosial, dan masa perkembangan. Penurunan fungsi intelektual secara umum menurut definisi Rick Heber diukur berdasarkan tes intelegensia standar paling sedikit satu deviasi standar (1 SD) di bawah rata-rata. Periode perkembangan mental menurut definisi ini adalah mulai dari lahir sampai umur 16 tahun. Gangguan adaptasi sosial dalam definisi ini dihubungkan dengan adanya penurunan fungsi intelektual. Menurut definisi ini tidak ada kriteria bahwa retardasi mental tidak dapat diperbaiki seperti definisi retardasi mental sebelumnya. ${ }^{4,7,8}$

Banyak pakar menyatakan bahwa definisi ini terlalu liberal, karena dengan batasan tes intelegensia di bawah satu deviasi standar (1 SD) terdapat hampir $16 \%$ dari populasi dapat digolongkan sebagai retardasi mental. ${ }^{2}$ Pada tahun 1973 melalui Manual on Terminology and Classfication in Mental Retardation Grossman merevisi definisi Heber tersebut. Menurut Grossman retardasi mental adalah penurunan fungsi intelektual yang menyeluruh secara bermakna dan secara langsung menyebabkan gangguan adaptasi sosial, dan bermanifestasi selama masa perkembangan. Menurut definisi ini penurunan fungsi intelektual yang bermakna berarti pada pengukuran uji intelegensia berada pada dua deviasi standar di bawah rata-rata. Berdasarkan kriteria ini ternyata kurang dari 3\% populasi yang dapat digolongkan sebagai retardasi mental. Periode perkembangan menurut definisi ini adalah mulai dari lahir sampai umur 18 tahun. Gangguan adaptasi sosial menurut definisi ini secara langsung disebabkan oleh penurunan fungsi intelektual. ${ }^{4,7,8}$

\section{Klasifikasi}

Uji intelegensia pertama kali diperkenalkan oleh seorang psikolog Perancis yang bernama Alfred Binet dan Theodore Simon pada tahun 1900. Pada tahun 1916 Dr Lewis Terman mengadaptasi pemeriksaan intelegensia berdasarkan skala Binet tersebut di Stanford University. Saat ini uji intelegensia tersebut dinamakan Stanford Binet Intelligence Scale yang sudah direvisi 4 kali yaitu tahun 1937, 1960, 1973, dan 1986.4,9,10

William Stern pada tahun 1912 membuat konsep intelligence quotient (IQ) sebagai suatu perbandingan antara mental age (MA) dan chronological age (CA) $4,5,10$

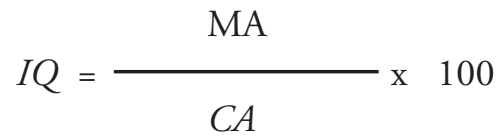

Pada tahun 1939 David Wechsler mempublikasikan suatu tes intelegensia yang mengukur fungsi intelektual yang lebih global. Uji ini kemudian disebut Wechsler Intelligence Scale for Children (WISC) yang kemudian direvisi tahun 1976 dan disebut Wechsler Intelligence Scale for Children Revised (WISC-R), dan direvisi kembali tahun 1990 yang disebut WISC third edition (WISC-III). Uji intelegensia tersebut dipakai untuk anak umur 6-16 tahun. ${ }^{4,5,10}$

Pada tahun 1966 dipublikasikan Wechsler Preschool and Primary Scale of Intelligence (WPPSI) yang kemudian direvisi tahun 1989 disebut WPPSI-R, untuk anak umur 4-61/2 tahun. ${ }^{2}$

Berdasarkan The ICD-10 Classification of Mental and Behavioural Disorders, WHO, Geneva tahun 1994 
retardasi mental dibagi menjadi 4 golongan yaitu :1,4,5,10

- Mild retardation (retardasi mental ringan), IQ5069

- Moderate retardation (retardasi mental sedang), IQ 35-49

- $\quad$ Severe retardation (retardasi mental berat), IQ 2034

- Profound retardation (retardasi mental sangat berat), $I Q<20$

\section{Retardasi mental ringan}

Retardasi mental ringan dikategorikan sebagai retardasi mental dapat dididik (educable). Anak mengalami gangguan berbahasa tetapi masih mampu menguasainya untuk keperluan bicara sehari-hari dan untuk wawancara klinik. Umumnya mereka juga mampu mengurus diri sendiri secara independen (makan, mencuci, memakai baju, mengontrol saluran cerna dan kandung kemih), meskipun tingkat perkembangannya sedikit lebih lambat dari ukuran normal. Kesulitan utama biasanya terlihat pada pekerjaan akademik sekolah, dan banyak yang bermasalah dalam membaca dan menulis. Dalam konteks sosiokultural yang memerlukan sedikit kemampuan akademik, mereka tidak ada masalah. Tetapi jika ternyata timbul masalah emosional dan sosial, akan terlihat bahwa mereka mengalami gangguan, misal tidak mampu menguasai masalah perkawinan atau mengasuh anak, atau kesulitan menyesuaikan diri dengan tradisi budaya. ${ }^{1,4}$

\section{Retardasi mental sedang}

Retardasi mental sedang dikategorikan sebagai retardasi mental dapat dilatih (trainable). Pada kelompok ini anak mengalami keterlambatan perkembangan pemahaman dan penggunaan bahasa, serta pencapaian akhirnya terbatas. Pencapaian kemampuan mengurus diri sendiri dan ketrampilan motor juga mengalami keterlambatan, dan beberapa diantaranya membutuhkan pengawasan sepanjang hidupnya. Kemajuan di sekolah terbatas, sebagian masih bisa belajar dasardasar membaca, menulis dan berhitung. ${ }^{1,4}$

\section{Retardasi mental berat}

Kelompok retardasi mental berat ini hampir sama dengan retardasi mental sedang dalam hal gambaran klinis, penyebab organik, dan keadaan-keadaan yang terkait. Perbedaan utama adalah pada retardasi mental berat ini biasanya mengalami kerusakan motor yang bermakna atau adanya defisit neurologis. ${ }^{1,4}$

\section{Retardasi mental sangat berat}

Retardasi mental sangat berat berarti secara praktis anak sangat terbatas kemampuannya dalam mengerti dan menuruti permintaan atau instruksi. Umumnya anak sangat terbatas dalam hal mobilitas, dan hanya mampu pada bentuk komunikasi nonverbal yang sangat elementer. ${ }^{1,4}$

\section{Etiologi}

Terjadinya retardasi mental tidak dapat dipisahkan dari tumbuh kembang seorang anak. Seperti diketahui faktor penentu tumbuh kembang seorang anak pada garis besarnya adalah ${ }^{3,4,5}$ faktor genetik/heredokonstitusional yang menentukan sifat bawaan anak tersebut dan faktor lingkungan. Yang dimaksud dengan lingkungan pada anak dalam konteks tumbuh kembang adalah suasana (milieu) dimana anak tersebut berada. Dalam hal ini lingkungan berfungsi sebagai penyedia kebutuhan dasar anak untuk tumbuh kembang.

Kebutuhan dasar anak untuk tumbuh kembang ini secara garis besar dapat digolongkan menjadi 3 golongan, yaitu: ${ }^{3}$

- Kebutuhan fisis-biomedis (asuh)

- Pangan (gizi, merupakan kebutuhan paling penting)

- Perawatan kesehatan dasar (Imunisasi, ASI, penimbangan bayi secara teratur, pengobatan sederhana, dan lain lain)

- Papan (pemukiman yang layak)

- Higiene, sanitasi

- Sandang

- Kesegaran jasmani, rekreasi

- Kebutuhan emosi/kasih sayang (asih). Pada tahuntahun pertama kehidupan hubungan yang erat, mesra dan selaras antara ibu dan anak merupakan syarat mutlak untuk menjamin suatu proses tumbuh kembang yang selaras, baik fisis, mental maupun sosial.

- Kebutuhan akan stimulasi mental (asah). Merupakan cikal bakal proses pembelajaran (pendidikan dan pelatihan) pada anak. Stimulasi mental ini membantu perkembangan mental- 
psikososial (kecerdasan, ketrampilan, kemandirian, kreativitas, kepribadian, moral-etika dan sebagainya). Perkembangan ini pada usia balita disebut sebagai perkembangan psikomotor.

Kelainan/penyimpangan tumbuh kembang pada anak terjadi akibat gangguan pada interaksi antara anak dan lingkungan tersebut, sehingga kebutuhan dasar anak tidak terpenuhi. Keadaan ini dapat menyebabkan morbiditas anak, bahkan dapat berakhir dengan kematian. Kalaupun kematian dapat diatasi, sebagian besar anak yang telah berhasil tetap hidup ini mengalami akibat menetap dari penyimpangan tersebut yang dikategorikan sebagai kecacatan, termasuk retardasi mental. Jelaslah bahwa dalam aspek pencegahan terjadinya retardasi mental praktek pengasuhan anak dan peran orangtua sangat penting. ${ }^{2}$

Etiologi retardasi mental dapat terjadi mulai dari fase pranatal, perinatal dan postnatal. Beberapa penulis secara terpisah menyebutkan lebih dari 1000 macam penyebab terjadinya retardasi mental, dan banyak diantaranya yang dapat dicegah. Ditinjau dari penyebab secara langsung dapat digolongkan atas penyebab biologis dan psikososial. Penyebab biologis atau sering disebut retardasi mental tipe klinis mempunyai ciri-ciri sebagai berikut: ${ }^{2,4,7,8}$

- Pada umumnya merupakan retardasi mental sedang sampai sangat berat

- Tampak sejak lahir atau usia dini

- Secara fisis tampak berkelainan/aneh

- Mempunyai latar belakang biomedis baik pranatal, perinatal maupun postnatal

- Tidak berhubungan dengan kelas sosial

Penyebab psikososial atau sering disebut tipe sosiokultural mempunyai ciri-ciri sebagai berikut

- Biasanya merupakan retardasi mental ringan

- Diketahui pada usia sekolah

- Tidak terdapat kelainan fisis maupun laboratorium

- Mempunyai latar belakang kekurangan stimulasi mental (asah)

- Ada hubungan dengan kelas sosial

Melihat struktur masyarakat Indonesia, golongan sosio ekonomi rendah masih merupakan bagian yang besar dari penduduk, dapat diperkirakan bahwa retardasi mental di Indonesia yang terbanyak adalah tipe sosio-kultural. ${ }^{2,3}$

Etiologi retardasi mental tipe klinis atau biologikal dapat dibagi dalam

1. Penyebab pranatal

- Kelainan kromosom

- Kelainan genetik /herediter

- Gangguan metabolik

- Sindrom dismorfik

- Infeksi intrauterin

- Intoksikasi

2. Penyebab perinatal

- Prematuritas

- Asfiksia

- Kernikterus

- Hipoglikemia

- Meningitis

- Hidrosefalus

- Perdarahan intraventrikular

3. Penyebab postnatal

- Infeksi (meningitis, ensefalitis)

- Trauma

- Kejang lama

- Intoksikasi (timah hitam, merkuri)

\section{Penyebab Pranatal}

\section{Kelainan kromosom}

Kelainan kromosom penyebab retardasi mental yang terbanyak adalah sindrom Down. Disebut demikian karena Langdon Down pada tahun 1866 untuk pertama kali menulis tentang gangguan ini, yaitu bayi yang mempunyai penampilan seperti mongol dan menunjukkan keterbelakangan mental seperti idiot. Hal ini tidak sepenuhnya benar, karena sebagian besar dari golongan ini termasuk retardasi mental sedang. Sindrom Down merupakan 10-32\% dari penderita retardasi mental. Diperkirakan insidens dari sindrom Down antara 1-1,7 per 1000 kelahiran hidup per tahun. Risiko timbulnya sindrom Down berkaitan dengan umur ibu saat melahirkan. Ibu yang berumur 20-25 tahun saat melahirkan mempunyai risiko 1:2000, sedangkan ibu yang berumur 45 tahun mempunyai risiko 1:30 untuk timbulnya sindrom Down. Analisis kromosom pada sindrom Down 95\% menunjukkan trisomi -21 , sedangkan 5\% sisanya merupakan mosaik dan translokasi .3,4,11

Kelainan kromosom lain yang bermanifestasi sebagai retardasi mental adalah trisomi-18 atau sindrom Edward, dan trisomi-13 atau sindrom Patau, sindrom Cri-du- 
chat, sindrom Klinefelter, dan sindrom Turner. Berdasarkan pengamatan ternyata kromatin seks, yang merupakan kelebihan kromosom -X pada laki-laki lebih banyak ditemukan di antara penderita retardasi mental dibandingkan laki-laki normal. Diperkirakan kelebihan kromosom-X pada laki-laki memberi pengaruh tidak baik pada kesehatan jiwa, termasuk timbulnya psikosis, gangguan tingkah laku dan kriminalitas.,11,12

Kelainan kromosom-X yang cukup sering menimbulkan retardasi mental adalah Fragile-X syndrome, yang merupakan kelainan kromosom-X pada band q27. Kelainan ini merupakan $X$-linked, dibawa oleh ibu. Penampilan klinis yang khas pada kelainan ini adalah dahi yang tinggi, rahang bawah yang besar, telinga panjang, dan pembesaran testis. Diperkirakan prevalens retardasi mental yang disebabkan fragile- $X$ syndrome pada populasi anak usia sekolah adalah $1: 2610$ pada laki-laki, dan 1: 4221 pada perempuan. ${ }^{3,12}$

\section{Kelainan metabolik}

Kelainan metabolik yang sering menimbulkan retardasi mental adalah Phenylketonuria (PKU), yaitu suatu gangguan metabolik dimana tubuh tidak mampu mengubah asam amino fenilalanin menjadi tirosin karena defisiensi enzim hidroksilase. Penderita laki-laki tenyata lebih besar dibandingkan perempuan dengan perbandingan 2:1. Kelainan ini diturunkan secara autosom resesif. Diperkirakan insidens $P K U$ adalah 1:12 000-15 000 kelahiran hidup. Penderita retardasi mental pada $P K U$ 66,7\% tergolong retardasi mental berat dan 33,3\% retardasi mental sedang. . $3,4^{4}$

Galaktosemia adalah suatu gangguan metabolisme karbohidrat disebabkan karena tubuh tidak mampu menggunakan galaktosa yang dimakan. Dengan diet bebas galaktosa bayi akan bertambah berat badannya dan fungsi hati akan membaik, tetapi menurut beberapa penulis perkembangan mental tidak mengalami perubahan. ${ }^{1,3,4}$ Penyakit Tay-Sachs atau infantile amaurotic idiocy adalah suatu gangguan metabolisme lemak, dimana tubuh tidak bisa mengubah zat-zat pralipid menjadi lipid yang diperlukan oleh sel-sel otak. Manifestasi klinis adalah nistagmus, atrofi nervus optikus, kebutaan, dan retardasi mental sangat berat. ${ }^{3,4}$ Hipotiroid kongenital adalah defisiensi hormon tiroid bawaan yang disebabkan oleh berbagai faktor (agenesis kelenjar tiroid, defek pada sekresi TSH atau TRH, defek pada produksi hormon tiroid). Kadang-kadang gejala klinis tidak begitu jelas dan baru terdeteksi setelah 6-12 minggu kemudian, padahal diagnosis dini sangat penting untuk mencegah timbulnya retardasi mental atau paling tidak meringankan derajat retardasi mental. Gejala klasik hipotiroid kongenital pada minggu pertama setelah lahir adalah miksedema, lidah yang tebal dan menonjol, suara tangis yang serak karena edema pita suara, hipotoni, konstipasi, bradikardi, hernia umbilikalis. Prevalens hipotiroid kongenital berkisar 1:4000 neonatus di seluruh dunia. ${ }^{1,13}$

Defisiensi yodium secara bermakna dapat menyebabkan retardasi mental baik di negara sedang berkembang maupun di negara maju. Diperkirakan 600 juta sampai 1 milyar penduduk dunia mempunyai risiko defisiensi yodium, terutama di negara sedang berkembang. Penelitian $\mathrm{WHO}^{1}$ mendapatkan 710 juta penduduk Asia, 227 juta Afrika, 60 juta Amerika Latin, dan 20-30 juta Eropa mempunyai risiko defisiensi yodium. Akibat defisiensi yodium pada masa perkembangan otak karena asupan yodium yang kurang pada ibu hamil meyebabkan retardasi mental pada bayi yang dilahirkan. Kelainan ini timbul bila asupan yodium ibu hamil kurang dari 20 ug (normal 80-150 ug) per hari. Dalam bentuk yang berat kelainan ini disebut juga kretinisme, dengan manisfestasi klinis adalah miksedema, kelemahan otot, letargi, gangguan neurologis, dan retardasi mental berat. Di daerah endemis, 1 dari 10 neonatus mengalami retardasi mental karena defisiensi yodium. ${ }^{1,13}$

\section{Infeksi}

Infeksi rubela pada ibu hamil triwulan pertama dapat menimbulkan anomali pada janin yang dikandungnya. Risiko timbulnya kelainan pada janin berkurang bila infeksi timbul pada triwulan kedua dan ketiga. Manifestasi klinis rubela kongenital adalah berat lahir rendah, katarak, penyakit jantung bawaan, mikrosefali, dan retardasi mental. ${ }^{1,3,4}$

Infeksi cytomegalovirus tidak menimbulkan gejala pada ibu hamil tetapi dapat memberi dampak serius pada janin yang dikandungnya. Manifestasi klinis antara lain hidrosefalus, kalsifikasi serebral, gangguan motorik, dan retardasi mental.

\section{Intoksikasi}

Fetal alcohol syndrome (FAS) merupakan suatu sindrom yang diakibatkan intoksikasi alkohol pada 
janin karena ibu hamil yang minum minuman yang mengandung alkohol, terutama pada triwulan pertama. Di negara Amerika Serikat FAS merupakan penyebab tersering dari retardasi mental setelah sindrom Down. Insidens FAS berkisar antara 1-3 kasus per 1000 kelahiran hidup. Pada populasi wanita peminum minuman keras insidens FAS sangat meningkat yaitu 21-83 kasus per 1000 kelahiran hidup, padahal di Eropa dan Amerika 8\% wanita merupakan peminum minuman keras. ${ }^{1,4,14}$

\section{Penyebab Perinatal}

Koch menulis bahwa $15-20 \%$ dari anak retardasi mental disebabkan karena prematuritas. Penelitian dengan 455 bayi dengan berat lahir $1250 \mathrm{~g}$ atau kurang menunjukkan bahwa 85\% dapat mempelihatkan perkembangan fisis rata-rata, dan $90 \%$ memperlihatkan perkembangan mental rata-rata. Penelitian pada 73 bayi prematur dengan berat lahir $1000 \mathrm{~g}$ atau kurang menunjukkan $I Q$ yang bervariasi antara 59-142, dengan $I Q$ rata-rata 94. Keadaan fisis anak-anak tersebut baik, kecuali beberapa yang mempunyai kelainan neurologis, dan gangguan mata. Penulis-penulis lain berpendapat bahwa semakin rendah berat lahirnya, semakin banyak kelainan yang dialami baik fisis maupun mental. . $3,4,15$ Asfiksia, hipoglikemia, perdarahan intraventrikular, kernikterus, meningitis dapat menimbulkan kerusakan otak yang ireversibel, dan merupakan penyebab timbulnya retardasi mental. ${ }^{3,15}$

\section{Penyebab Postnatal}

Faktor-faktor postnatal seperti infeksi, trauma, malnutrisi, intoksikasi, kejang dapat menyebabkan kerusakan otak yang pada akhirnya menimbulkan retardasi mental. ${ }^{1,3,4}$

\section{Etiologi pada Kelompok Sosio-Kultural}

Proses psikososial dalam keluarga dapat merupakan salah satu penyebab retardasi mental. Sebenarnya bermacammacam sebab dapat bersatu untuk menimbulkan retardasi mental. Proses psikososial ini merupakan faktor penting bagi retardasi mental tipe sosio-kultural, yang merupakan retardasi mental ringan., ${ }^{2,4}$

\section{Diagnosis}

Diagnosis retardasi mental tidak hanya didasarkan atas tes intelegensia saja, melainkan juga dari riwayat penyakit, laporan dari orangtua, laporan dari sekolah, pemeriksaan fisis, laboratorium, pemeriksaan penunjang. Yang perlu dinilai tidak hanya intelegensia saja melainkan juga adaptasi sosialnya. Dari anamnesis dapat diketahui beberapa faktor risiko terjadinya retardasi mental. ${ }^{1,4,5}$

Pemeriksaan fisis pada anak retardasi mental biasanya lebih sulit dibandingkan pada anak normal, karena anak retardasi mental kurang kooperatif. Selain pemeriksaan fisis secara umum (adanya tanda-tanda dismorfik dari sindrom-sindrom tertentu) perlu dilakukan pemeriksaan neurologis, serta penilaian tingkat perkembangan. Pada anak yang berumur diatas 3 tahun dilakukan tes intelegensia., 4

Pemeriksaan Ultrasonografi (USG) kepala dapat membantu menilai adanya kalsifikasi serebral, perdarahan intra kranial pada bayi dengan ubun-ubun masih terbuka. Pemeriksaan laboratorium dilakukan atas indikasi, pemeriksaan ferriklorida dan asam amino urine dapat dilakukan sebagai screening $P K U$. Pemeriksaan analisis kromosom dilakukan bila dicurigai adanya kelainan kromosom yang mendasari retardasi mental tersebut. Beberapa pemeriksaan penunjang lain dapat dilakukan untuk membantu seperti pemeriksaan BERA, CT-Scan, dan MRI. ${ }^{4,5}$

Kesulitan yang dihadapi adalah kalau penderita masih dibawah umur 2-3 tahun, karena kebanyakan tes psikologis ditujukan pada anak yang lebih besar. Pada bayi dapat dinilai perkembangan motorik halus maupun kasar, serta perkembangan bicara dan bahasa. Biasanya penderita retardasi mental juga mengalami keterlambatan motor dan bahasa. ${ }^{4,5}$

\section{Tatalaksana}

\section{Tatalaksana Medis}

Obat-obat yang sering digunakan dalam pengobatan retardasi mental adalah terutama untuk menekan gejala-gejala hiperkinetik. Metilfenidat (ritalin) dapat memperbaiki keseimbangan emosi dan fungsi kognitif. Imipramin, dekstroamfetamin, klorpromazin, flufenazin, fluoksetin kadang-kadang dipergunakan oleh psikiatri anak. Untuk menaikkan kemampuan 
belajar pada umumnya diberikan tioridazin (melleril), metilfenidat, amfetamin, asam glutamat, gamma aminobutyric acid (GABA). ${ }^{3,4,16}$

\section{Rumah Sakit/Panti Khusus}

Penempatan di panti-panti khusus perlu dipertimbangkan atas dasar: kedudukan sosial keluarga, sikap dan perasaan orangtua terhadap anak, derajat retardasi mental, pandangan orangtua mengenai prognosis anak, fasilitas perawatan dalam masyarakat, dan fasilitas untuk membimbing orangtua dan sosialisasi anak.

Kerugian penempatan di panti khusus bagi anak retardasi mental adalah kurangnya stimulasi mental karena kurangnya kontak dengan orang lain dan kurangnya variasi lingkungan yang memberikan kebutuhan dasar bagi anak. ${ }^{3}$

\section{Psikoterapi}

Psikoterapi dapat diberikan kepada anak retardasi mental maupun kepada orangtua anak tersebut. Walaupun tidak dapat menyembuhkan retardasi mental tetapi dengan psikoterapi dan obat-obatan dapat diusahakan perubahan sikap, tingkah laku dan adaptasi sosialnya. ${ }^{3,4}$

\section{Konseling}

Tujuan konseling dalam bidang retardasi mental ini adalah menentukan ada atau tidaknya retardasi mental dan derajat retardasi mentalnya, evaluasi mengenai sistem kekeluargaan dan pengaruh retardasi mental pada keluarga, kemungkinan penempatan di panti khusus, konseling pranikah dan pranatal.

\section{Pendidikan}

Pendidikan yang penting disini bukan hanya asal sekolah, namun bagaimana mendapatkan pendidikan yang cocok bagi anak yang terbelakang ini. Terdapat empat macam tipe pendidikan untuk retardasi mental. ${ }^{1,3,4}$

- Kelas khusus sebagai tambahan dari sekolah biasa

- Sekolah luar biasa C

- Panti khusus

- Pusat latihan kerja (sheltered workshop)

\section{Pencegahan}

Pencegahan retardasi mental dapat primer (mencegah timbulnya retardasi mental), atau sekunder (mengurangi manifestasi klinis retardasi mental). Sebabsebab retardasi mental yang dapat dicegah antara lain infeksi, trauma, intoksikasi, komplikasi kehamilan, gangguan metabolisme, kelainan genetik. ${ }^{1,4,5,6}$

\section{Kesimpulan}

Retardasi mental merupakan masalah bidang kesehatan masyarakat, kesejahteraan sosial dan pendidikan baik pada anak yang mengalami retardasi mental tersebut maupun keluarga dan masyarakat.

Definisi retardasi mental harus mencakup bidang kognitif (intelegensia) dan adaptasi sosial yang timbul pada masa perkembangan.

Klasifikasi retardasi mental saat ini yang terbanyak dipakai adalah The ICD-10 Classification of mental and Behavioural Disorders, WHO, Geneva tahun 1994, yaitu :

- Mild retardation (Retardasi mental ringan), IQ 50-69

- Moderate retardation (Retardasi mental sedang), IQ 35-49

- Severe retardation (Retardasi mental berat), IQ2034

- Profound retardation (Retardasi mental sangat berat), $I Q<20$

Mengingat besarnya beban yang ditanggung oleh penderita retardasi mental, keluarga, dan masyarakat maka pencegahan terhadap timbulnya retardasi mental dan diagnosis dini merupakan pilihan terbaik.

\section{Daftar Pustaka}

1. WHO. Primary prevention of mental neurological and psychosocial disorders. Geneva, WHO 1998: h. 8-53.

2. Payne JS, Patton JR. Mental retardation. Columbus: Bell \& Howell Company,1981. h. 1-466.

3. Sularyo TS. Tumbuh kembang anak dengan minat khusus pada aspek pencegahan Tuna grahita. Disampaikan pada seminar sehari jangan sampai anakku tuna grahita, Jakarta, 21 November, 1992.

4. Prasadio T. Gangguan psikiatrik pada anak-anak dengan retardasi mental. Disertasi. Surabaya: Universitas Airlangga, 1976.

5. Lumbantobing SM. Anak dengan mental terbelakang. 
Jakarta: Balai Penerbit FKUI, 1997. h. 1-85.

6. Ramelan W. Tuna grahita bawaan: latar belakang genetik dan deteksi dini pada orangtua. Disampaikan pada seminar sehari jangan sampai anakku tuna grahita, Jakarta, 21 November, 1992.

7. Valente M, Tarjan G. Etiology factors in mental retardation. Psychiatric Ann Repr 1974:8-14.

8. Sidiarto LD. Tuna grahita ditinjau dari aspek neurologis. Disampaikan pada seminar sehari jangan sampai anakku tuna grahita, Jakarta, 21 November 1992.

9. Shelton JR. Theories of development and learning. Dalam: Wolraich ML, penyunting. Disorders of development learning a practical guide of assesment and management. Edisi ke-2. St. Louis, 1996. h. 3-39.

10. Glascoe FP. Development screening. Dalam: Wolraich ML, penyunting. Disorders of development learning a practical guide of assesment and management. Edisi ke2. St. Louis, 1996. h. 89-128.

11. Balarajan R, Raleigh VS, Botting B. Mortality from congenital malformations in England and Wales: variations by mother's country of birth. Arch Diss in Child 1989; 64:1457-62.

12. Turner G, Robinson H, et al. Preventive screening for the fragile X syndrome. N Eng J Med 1986; 315:607-9.

13. Fisher DA. The thyroid. Dalam: Kaplan SA, penyunting. Clinical pediatric endocrinology. Philadelphia: W B Saunders Co,1990. h. 87-126.

14. Regier DA, Farmer ME, et al. Comorbidity of mental disorders with alcohol and other drug abuse, result from the epidemiologic catchment area (ECA) study. JAMA 1990; 264:2511-8.

15. Rydhstroem $\mathrm{H}$. The relationship of birth weight and birth weight discordance to cerebral palsy or mental retardation later in life for twins weighing less than 2500 grams. Am J Obstet Gynecol 1995; 173:680-6.

16. Simons JQ, Tymchuck AJ, Valente M. Treatment and care of the mentally retarded. A psychiatric ann repr 1974:15-20. 